\title{
An epidemic of ECHO 6 virus infection
}

\begin{abstract}
A. S. MARY
M.B. Ch.B.(Bagdad), M.R.C.P.(Lond.)

Medical Registrar

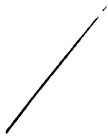

\section{Summary}

Fourteen cases of infection with ECHO 6 virus in the Chelmsford area from August to December 1968 are described. A comparative account of the seasonal, geographical and age incidence is given, and its relationship to certain epidemiological aspects is discussed.

Aseptic meningitis occurred in eleven patients, pharyngitis in seven and myalgia in five. One patient suffered from pericarditis, a manifestation of this infection which has not hitherto been recognized. Another patient suffering from aseptic meningitis developed nephritis during the course of the illness, an association which has not been reported with ECHO 6 infection.
\end{abstract}

\author{
J. H. Swallow \\ M.A., M.B.(Cantab), M.R.C.P.(Lond.)
}

Consultant Physician
Chelmsford Group of Hospitals
A relapse occurred in one patient with meningitis. No permanent ill-effects followed in any case.

\section{Introduction}

It is almost 20 years since the first ECHO virus was recognized. During a search for polio-viruses, a virus was found in tissue culture which was not neutralized by antibodies to polio-viruses or to Coxsackie viruses, and which was incapable of producing illness in suckling mice or monkeys. These enteric viruses were then described as Orphan because they were not pathogenic to laboratory animals, and because their relationship to illness was obscure. Subsequently they were defined as the Enteric (from their source), Cytopathogenic (from the changes produced in monkey and human cells in tissue culture), Human (in origin) and Orphan group of viruses (Science, 1955). To date thirty-one ECHO virus types distinguished by antigenic properties have been recognized. However, some reclassification is taking place; thus, type 8 has been found to be related to type 1 , and types 10 and 28 are now included in the reoviruses and rhinoviruses, respectively.

ECHO type 6 is now well established as a not uncommon cause of aseptic meningitis (Winkelstein et al., 1957; Lepow et al., 1962; Peckham, 1964). Other syndromes attributed to infection with this type are encephalitis, lymphadenopathy and muscle weakness (Winkelstein et al., 1957); skin rashes, respiratory infections, myalgia and a Bornholm-like illness (Karzon \& Barron, 1962; Peckham, 1964). The association with diarrhoea in children is not definitely established (Sommerville, 1958; Kibrick,1965).

During the latter half of 1968 a small epidemic of ECHO 6 virus infection occurred in mid-Essex. The affected patients exhibited many of the recognized syndromes attributable to this infection, and some features not previously described.

\section{Case material}

During the months of August to December 1968, fourteen patients were admitted to the acute medical and paediatric wards of this hospital group, from whom ECHO 6 was isolated and in whom the clinical illness was attributed to this infection. Ten patients were males and four females; seven were adults and seven children (Table 1).

Virus isolation was achieved using standard laboratory techniques. Specimens likely to be bacteriologically sterile were inoculated directly on to tissue culture material, while contaminated specimens, such as faeces, were suspended in buffered saline, centrifuged and treated with antibiotics. In the case of throat swabs and washings, sufficient amphotericin B solution was added to the culture medium to give a final concentration of $2.5 \mu \mathrm{g} / \mathrm{ml}$. The cells used were monkey kidney cells, supplied by the National Institute for Medical Research, and Hela cells maintained in the laboratories. Tubes were incubated for at least 2 weeks before they were discarded as negative. When cytopathic changes occurred in the second passage of a culture, the virus was identified by a neutralization test, using typing sera provided by the Standards Laboratory, Central Public Health Laboratory, Colindale. These covered all types of polio viruses, Coxsackie B types 1-6, ECHO 6 virus and herpes simplex, but no attempt was made to isolate strains of Coxsackie $\mathbf{A}$ virus, which would have required the inoculation of suckling mice. 
TABLE 1. Clinical details of ECHO 6 virus infections, Chelmsford 1968

\begin{tabular}{|c|c|c|c|c|c|c|c|c|c|c|}
\hline $\begin{array}{l}\text { Case } \\
\text { No. }\end{array}$ & Age & Sex & $\begin{array}{l}\text { Presenting } \\
\text { clinical } \\
\text { syndrome }\end{array}$ & $\begin{array}{c}\text { Duration } \\
\text { of } \\
\text { illness }\end{array}$ & Meningism & Nephritis & Pharyngitis & $\begin{array}{l}\text { Cervical } \\
\text { lymph nodes }\end{array}$ & Myalgia & $\begin{array}{c}\text { Abdominal } \\
\text { pain }\end{array}$ \\
\hline 1 & 35 & F & Myalgia & 5 & - & - & - & - & + & + \\
\hline 2 & 31 & $\mathbf{M}$ & Meningitis & 4 & + & - & + & - & + & - \\
\hline 3 & 30 & $\mathbf{F}$ & Meningitis & 3 & + & - & - & - & - & - \\
\hline 4 & 26 & $\mathbf{M}$ & Meningitis & 4 & + & - & + & + & + & + \\
\hline 5 & 28 & $\mathbf{M}$ & Pericarditis & 5 & - & - & - & - & + & - \\
\hline 6 & 24 & $\mathbf{F}$ & Meningitis & 5 & + & - & + & + & + & - \\
\hline 7 & 12 & $\mathbf{F}$ & Meningitis & 5 & + & + & - & + & - & + \\
\hline 8 & 10 & $\mathbf{M}$ & Meningitis & 5 & + & - & + & + & - & - \\
\hline 9 & 8 & $\mathbf{M}$ & Meningitis & 6 & + & - & - & - & - & + \\
\hline 10 & 6 & $\mathbf{M}$ & Meningitis & 3 & + & - & - & - & - & - \\
\hline 11 & 5 & $\mathbf{M}$ & Meningitis & 3 & + & - & $\div$ & + & - & - \\
\hline 12 & 5 & $\mathbf{M}$ & Pharyngitis & 3 & + & - & + & - & - & - \\
\hline 13 & 5 & $\mathbf{M}$ & Meningitis & 4 & + & _- & + & - & - & - \\
\hline $14(a)^{*}$ & 27 & $\mathbf{M}$ & Meningitis & 6 & + & - & - & - & - & - \\
\hline $14(b)^{*}$ & 27 & $\mathbf{M}$ & Meningitis & 6 & + & - & - & - & - & - \\
\hline
\end{tabular}

* (a) and (b), the first and second admissions of Case 14.

\section{Clinical features}

Of the fourteen patients, eleven presented with meningitis, one with chest wall myalgia, one with pericarditis and one with pharyngitis. Other syndromes manifested by the patients included conjunctivitis, pharyngitis with cervical lymphadenopathy, abdominal pain, and glomerulonephritis. In many of the patients the overall picture was thus composed of several of these syndromes (Table 1). On admission all patients were febrile, ranging from $37 \cdot 2^{\circ}$ to $39 \cdot 8^{\circ} \mathrm{C}$.

The main syndromes are considered under five headings:

\section{Aseptic meningitis}

In eleven patients, the onset of illness was acute with fever, headache and signs of meningeal irritation; vomiting occurred in eight of these patients, and photophobia in six, of which one had conjunctivitis. Encephalitic manifestations as shown by extreme restlessness and excitement, or drowsiness, were present in four patients, each of whom had fever over $38.3^{\circ} \mathrm{C}$ on admission. Lumbar puncture was performed in all eleven patients during their first $24 \mathrm{hr}$ in hospital. Pleocytosis was present in ten. Polymorphonuclear leucocytes predominated in eight patients with counts varying from fourteen to 580 cells $/ \mathrm{mm}^{3}$; in patients no. 9 and no. 14 , on the 6 th and 7 th day of admission respectively, repeat spinal fluid examination showed change to predominant lymphocytosis. Protein levels ranged from 10 to $80 \mathrm{mg} / 100 \mathrm{ml}$, and glucose from 38 to 82 $\mathrm{mg} / 100 \mathrm{ml}$ (Table 2). The Lange colloidal gold curve was normal and the WR negative in all spinal fluid specimens. No bacteria were seen in stained films, and none isolated on aerobic and anaerobic culture. ECHO 6 virus was isolated from the CSF in eight of these eleven patients, including the one patient where no increase in white cells was demonstrated (Case no. 7). There was no discernible relationship between the cell counts, protein or glucose levels; nor between the degree of the CSF abnormalities and the clinical course. The patients showing the highest cell counts and protein levels were not more severely ill than the other patients. The CSF returned to normal usually after 8-10 days (Fig. 1).

A 27-year-old man (Case no. 14) made a clinical recovery in 6 days, and left hospital on the 16th day, after his spinal fluid had returned to normal. His general health continued to improve at home during the next 2 weeks, but then he had to be readmitted with a recurrence of aseptic meningitis. This second illness lasted 6 days. Polymorphonuclear leucocytosis predominated in the CSF on both occasions (Fig. 1 and Table 2).

\section{Myalgia}

Approximately $16 \mathrm{hr}$ prior to admission a 37 -yearold woman (Case no. 1) developed bilateral lower chest pain, which was worse on inspiration and associated with tenderness at the site of the pain. Following this she experienced pain in the left side of the neck, and in the abdomen. Her temperature was never recorded higher than $37 \cdot 2^{\circ} \mathrm{C}$. There were no other physical signs. X-ray of chest and abdomen, ECG and white cell count were normal. ECHO 6 virus was isolated from the stool.

Abdominal pain was a prominent symptom in three other patients; this was unassociated with gastro-intestinal symptoms, and therefore quite possibly also myalgic.

Muscle pains, either the generalized aching type experienced in influenza or localized to several distinct sites, were complained of by four other patients. 
An epidemic of ECHO 6 virus infection

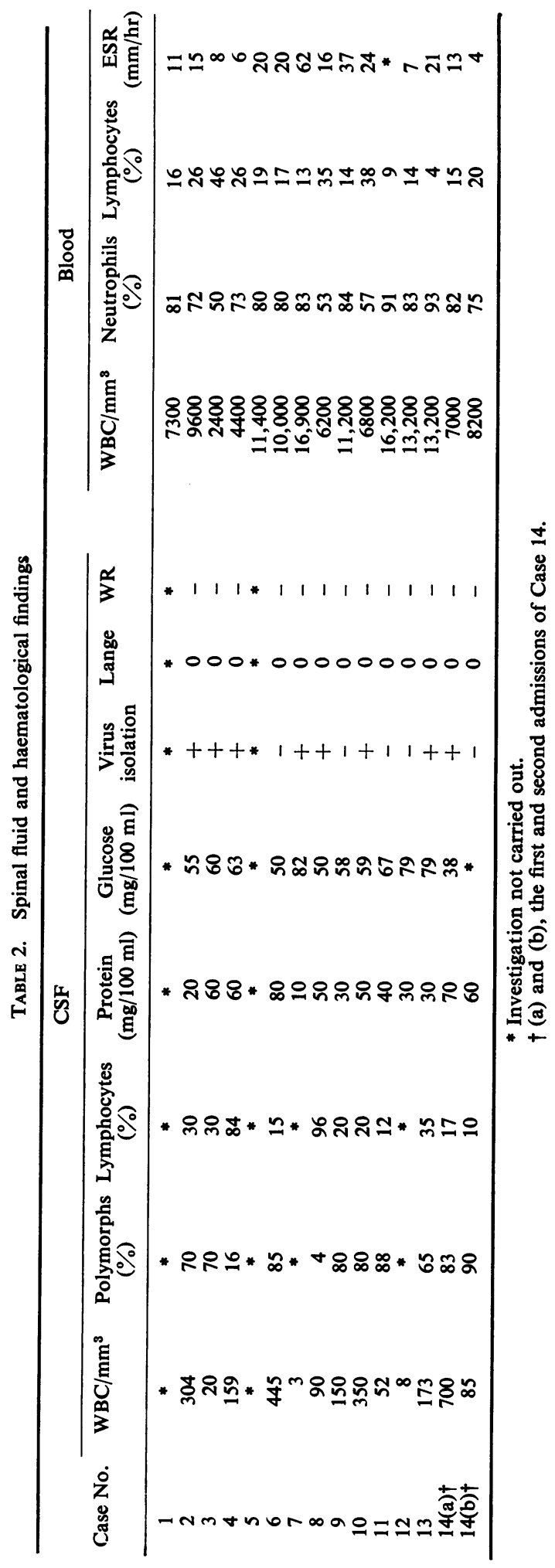




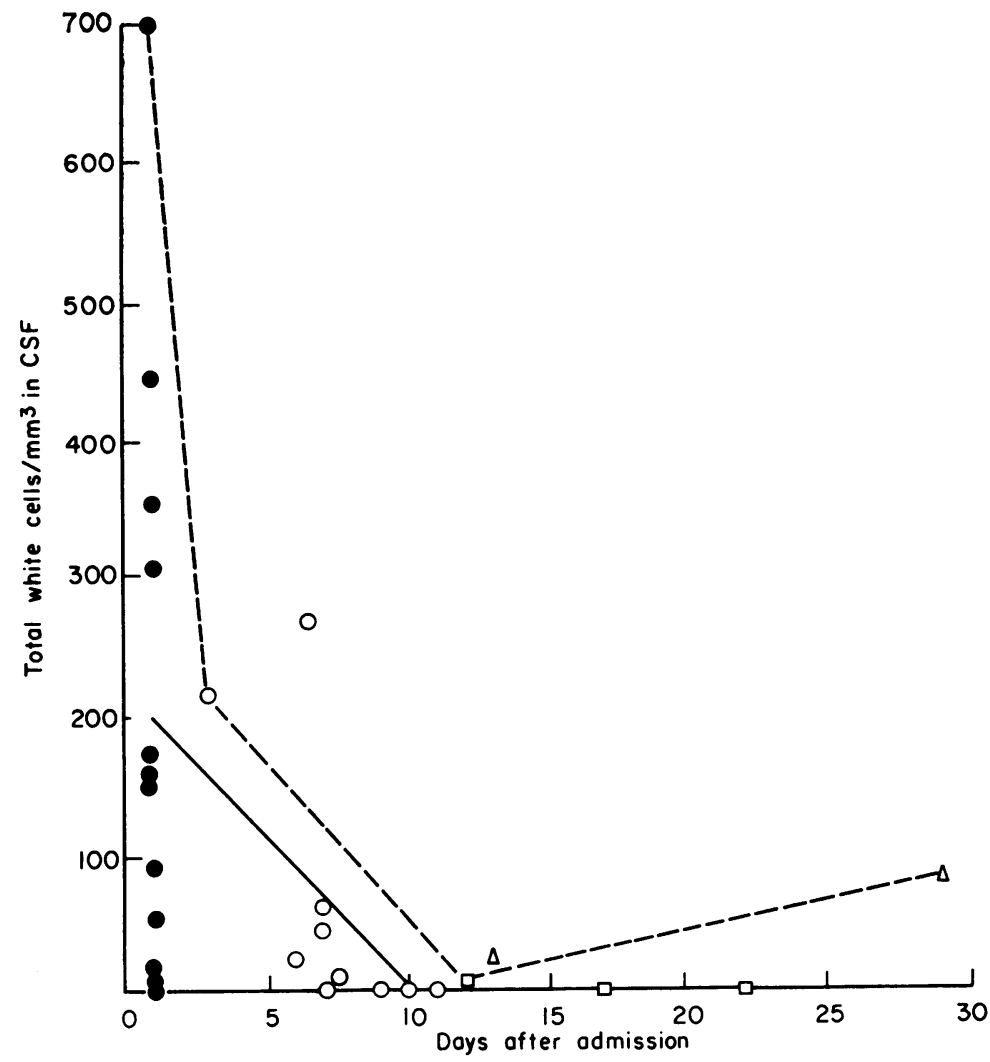

FIG. 1. CSF pleocytosis in ECHO 6 virus meningitis. ---, Case 14. - , means of CSF cell counts. - First lumbar puncture; $O$, second lumbar puncture; $\square$, third lumbar puncture; $\triangle$, fourth lumbar puncture.

\section{Pericarditis}

Some $16 \mathrm{hr}$ prior to admission, a 28 -year-old man (Case no. 5) developed a dull ache across the front of the chest, which was worse on movement and on inspiration. He also complained of headache and sweating, and was febrile on admission $\left(38 \cdot 2^{\circ} \mathrm{C}\right)$. A pericardial friction rub was never heard, but serial ECG tracings showed transient ST elevation with upward coveing of this segment in standard leads 1 and 2, aVL, and V5-6 (Fig. 2). There was no evidence to suggest development of a pericardial effusion. Chest X-ray was normal. The pain and fever settled in 3 days. White cell count and repeated ASO titres were normal. No pathogenic organisms were isolated from sputum or blood. ECHO 6 virus was isolated from his stool. There was no suggestion of pericarditis in any of the other patients.

\section{Pharyngitis}

A 5-year-old boy (Case no. 12) presented with fever of $38 \cdot 3^{\circ} \mathrm{C}$, pharyngitis and meningism. The white cell count was $13,200 / \mathrm{mm}^{3}$ with $83 \%$ polymorphs. MSU, chest X-ray and CSF were normal. No pathogenic bacteria were cultured from throat swab, urine or CSF, but ECHO 6 virus was isolated from both throat swab and faeces. One of the patients presenting with aseptic meningitis (Case no. 11) had a frank follicular tonsillitis with cervical lymphadenopathy; ECHO 6 virus was isolated from the throat swab. Pharyngitis was present in five other patients, three of whom had enlarged cervical lymph nodes. One patient had enlarged cervical lymph glands but no pharyngitis.

\section{Nephritis}

Proteinuria was detected on routine urine testing in a 12-year-old girl who presented with aseptic meningitis (Case no. 7). Laboratory examination of a clean-catch specimen confirmed the proteinuria, and also showed the presence of microscopic haematuria and many epithelial cells in the deposit; no bacteria were seen or isolated on culture. Blood 


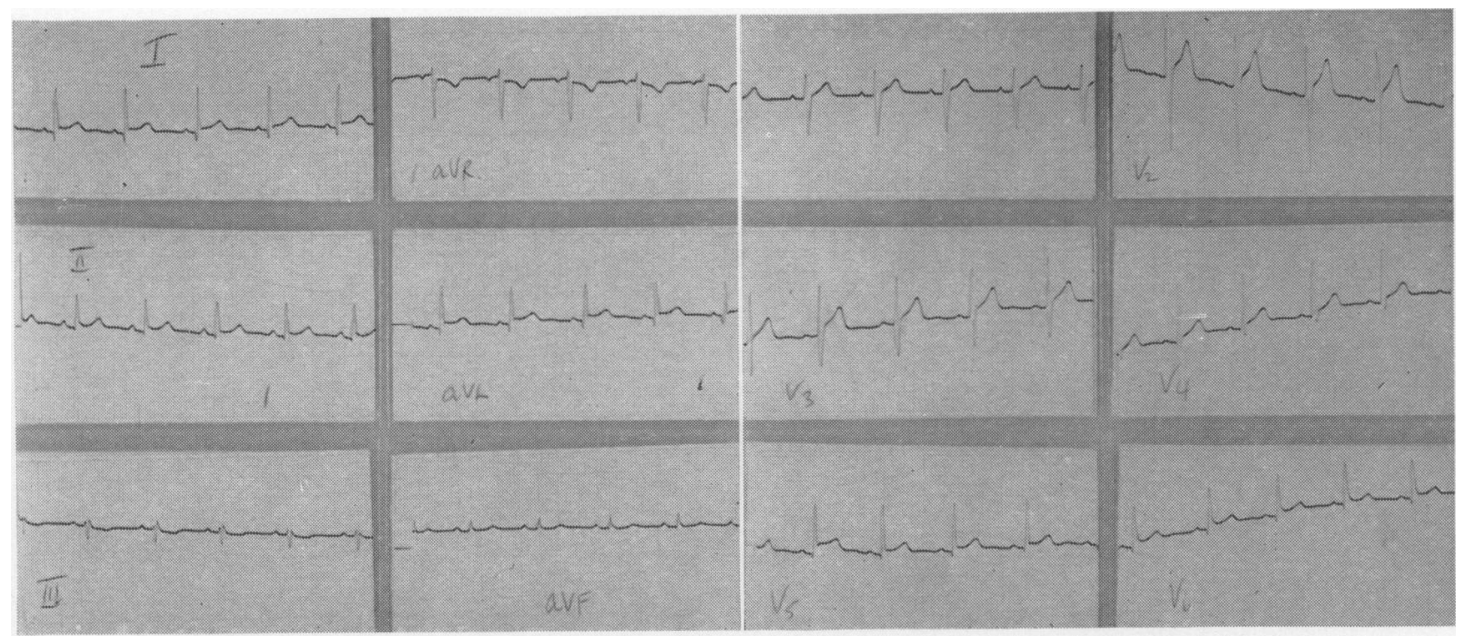

FIG. 2. ECG showing changes of pericarditis.

urea was not elevated. The girl made a clinical recovery in 5 days, and repeated urine examination thereafter was normal. Urine abnormalities were not detected in any other patient.

In all patients the illness was of short duration, and all clinical abnormalities had disappeared within a week of admission. As mentioned above, one patient (Case no. 14) showed a biphasic course.

\section{Other laboratory findings}

Blood

A polymorphonuclear leucocyte count of 8000 / $\mathrm{mm}^{3}$ was found in seven patients; one patient had neutropenia (Case no. 3). An ESR of $16 \mathrm{~mm}$ or above ( $1 \mathrm{hr}$ Westergren) was recorded in seven patients (Table 2).

\section{Virus isolation}

Isolations from stools were mostly from specimens collected during the 1st week of the illness, though in one patient ECHO 6 virus was isolated 14 days after admission to hospital. From the CSF most isolations were from the fluid obtained at lumbar puncture during the first $24 \mathrm{hr}$ in hospital (Table 3).

\section{Discussion}

The peak incidence of ECHO 6 virus infection in Chelmsford occurred in the autumn. This seasonal pattern corresponded with that seen in England and Wales during 1968, and to a lesser extent in 1967 when there was no national epidemic (Tables 4 and 5 and Fig. 3). No ECHO 6 virus was isolated in the Chelmsford area during 1967. The incidence of ECHO 6 virus infection in New York in 1955 had an earlier peak, in July and August (Karzon \&
TABLe 3. Virus isolation

\begin{tabular}{cccc}
\hline $\begin{array}{c}\text { Case } \\
\text { No. }\end{array}$ & CSF & Faeces & $\begin{array}{c}\text { Throat } \\
\text { swab }\end{array}$ \\
\hline 1 & 0 & + & 0 \\
2 & + & ++ & 0 \\
3 & + & + & 0 \\
4 & + & + & 0 \\
5 & 0 & + & 0 \\
6 & - & ++ & 0 \\
7 & + & 0 & 0 \\
8 & + & + & 0 \\
9 & - & + & + \\
10 & + & + & + \\
11 & - & 0 & + \\
12 & - & + & + \\
13 & ++ & + & + \\
$14(a) *$ & ++ & + & 0 \\
$14(b) *$ & - & 0 & 0 \\
\hline
\end{tabular}

+ , virus isolated once; ++ , virus isolated twice; - , virus not isolated; 0 , isolation not attempted.

* (a) and (b), the first and second admissions of case 14 .

Barron, 1962). The seasonal pattern shown in the national and Chelmsford figures (Fig. 3) can speculatively be attributed to the increased ease of viral transmission occasioned by more frequent person-to-person contact in closed places at the start of the cold weather, while the fall in incidence over the next several weeks may relate to the acquisition of immunity and disappearance of ECHO 6 virus carriers. During the period when these patients were observed, a considerable number of individuals were seen in the same hospital group with similar syndromes but from whom no pathogens were isolated, which raises the distinct possibility of a higher incidence of ECHO 6 virus infection than was 


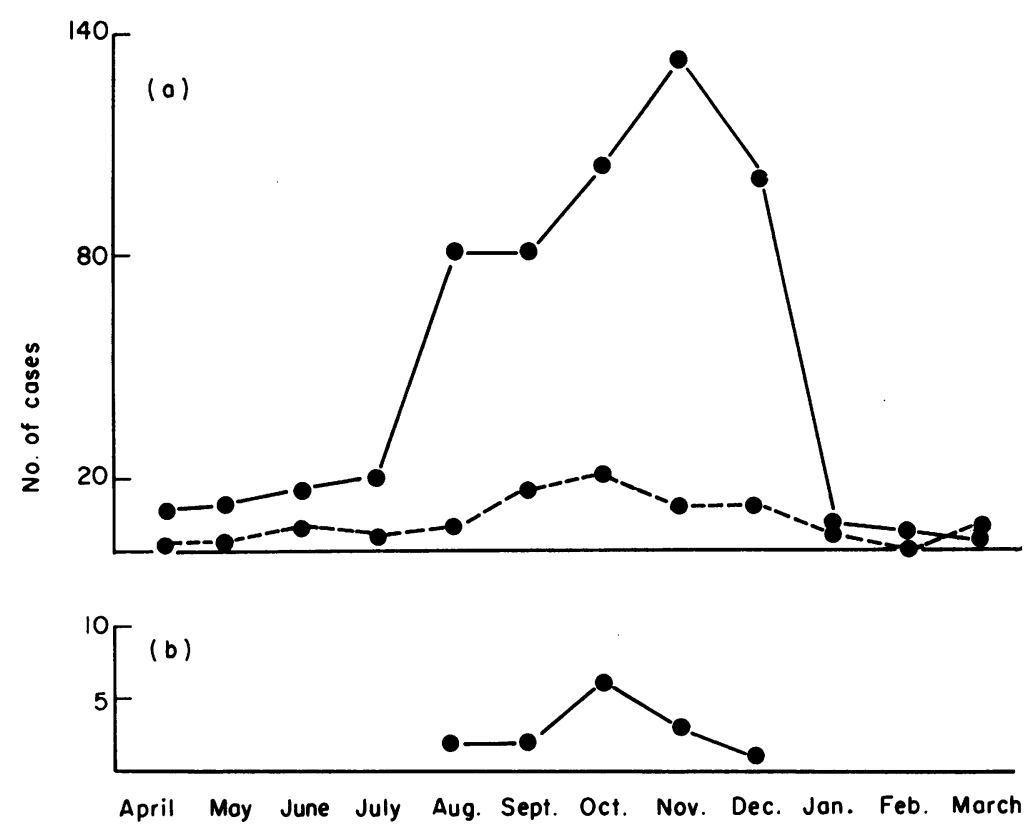

Fig. 3. Seasonal incidence of ECHO 6 virus isolation. (a) England and Wales, 1967 (O) and 1968 (

TABLE 4. Respiratory, cardiac and neurological infections due to ECHO 6 virus 1968

\begin{tabular}{|c|c|c|c|c|c|c|c|c|c|c|c|c|c|}
\hline & Total & Jan. & Feb. & Mar. & Apr. & May & June & July & Aug. & Sept. & Oct. & Nov. & Dec. \\
\hline \multicolumn{14}{|l|}{ Respiratory } \\
\hline England and Wales* & 42 & 4 & & & 2 & & & 3 & 3 & 5 & 8 & 17 & \\
\hline Chelmsford & 1 & & & & & & & & & 1 & & & \\
\hline \multicolumn{14}{|l|}{ Cardiac } \\
\hline England and Wales* & 3 & & & & & & & & & 1 & 2 & & \\
\hline Chelmsford & 1 & & & & & & & & 1 & & & & \\
\hline \multicolumn{14}{|l|}{ CNS } \\
\hline England and Wales* & $\begin{array}{r}302 \\
12\end{array}$ & 2 & 3 & 1 & & 3 & 11 & 12 & 51 & 52 & 70 & 97 & 1 \\
\hline
\end{tabular}

* Permission to use these figures was given by the Central Public Health Laboratory, Colindale.

TABLE 5. ECHO 6 virus infections 1967 and 1968

\begin{tabular}{|c|c|c|c|c|c|c|c|c|c|c|c|c|c|}
\hline & Total & Jan. & Feb. & Mar. & Apr. & May & June & July & Aug. & Sept. & Oct. & Nov. & Dec. \\
\hline England and Wales 1967* & 87 & 12 & 6 & - & 6 & 1 & 1 & 5 & 4 & 6 & 15 & 20 & 11 \\
\hline England and Wales 1968* & 539 & 7 & 4 & 3 & 3 & 4 & 15 & 21 & 66 & 68 & 107 & 1391 & 102 \\
\hline Chelmsford 1968 & 14 & - & - & - & - & - & - & - & 2 & 2 & 6 & 3 & 1 \\
\hline
\end{tabular}

*Permission to use these figures was given by the Central Public Health Laboratory, Colindale.

positively identified. As in the epidemic of aseptic meningitis due to ECHO 6 virus infection in New York (Karzon \& Barron, 1962), children were especially affected in Chelmsford, six boys and one girl. This is possibly due to immunity in adults acquired following exposure to infection in earlier life.
There was a contact history between Cases 11 and 12 , who were 5 -year-old playmates. The interval between the onsets of their illnesses was 3-4 days, which accords with the incubation period suggested in other outbreaks (Winkelstein et al., 1957). It is not certain, of course, whether these boys were infected from a common source. No other episodes 
of illness occurred in the families of these or any other patients in the series around the period covered by this epidemic. The rate of ECHO 6 virus isolation in healthy contacts of clinically affected patients is higher than in the general population at the same time (Karzon \& Barron, 1962). The first of these two children presented with aseptic meningitis (Case no. 11), and the second with an upper respiratory tract infection (Case no. 12), thus demonstrating the recognized variability in clinical syndromes that can be caused by the same strain of ECHO virus.

Pericarditis has been recorded in infections with ECHO virus types 1 and 9 (Kibrick, 1964), but not hitherto with type 6. A 12-year-old girl (Case no. 7) who presented with aseptic meningitis, developed a mild nephritis during the course of this illness. Acute glomerulonephritis has been reported to occur during the course of infection with ECHO virus type 9 in two cases (Yuceoglu, Berkovich \& Minkowitz, 1966) but not previously in association with type 6 infection. Diarrhoea has been reported in ECHO type 6 epidemics (Karzon \& Barron, 1962; Peckham, 1964); but, in comparison with children suffering from respiratory infection as control, Sommerville (1958) encountered only a slight excess of ECHO virus isolation in children with diarrhoea. Only one of our patients had diarrhoea. Nausea and vomiting occurred in ten of our fourteen patients, but these symptoms were essentially part of the meningitic illness, rather than primarily gastroenterological.

As in previous epidemics of ECHO type 6 virus infection, our patients had illnesses of only moderate severity from which they rapidly recovered without sequelae. The severity and course of the illness were not related to the haematological or cerebrospinal fluid abnormalities. One patient (Case no. 14 showed a biphasic course, which has previously been observed by Karzon \& Barron (1962). The explanation for this variability in response to infection is not understood; Webb (1968) suggests that host immunity may be the determining factor.

The virus is most commonly isolated from the stool, followed by throat swab and then CSF (Winkelstein et al., 1957; Karzon \& Barron, 1962; Peckham, 1964). The stool was the commonest source of ECHO 6 virus in this series. It would seem probable that ECHO 6 virus infection is transmitted, like the enteric infections, by faecally contaminated food or drink. The longest period during which virus was isolated from the stools of any of our cases was 14 days, similar to the 17 days in the 1955 New York ECHO 6 virus epidemic (Karzon \& Barron, 1962).

\section{Acknowledgments}

We wish to thank Dr R. Pilsworth, Director of the Public Health Laboratory, Chelmsford, and the Medical Consultant Staff of the Chelmsford Group of Hospitals, for allowing us to study their patients, and Miss B. J. Wall, Chief Technician of the Public Health Laboratory, Chelmsford, for her technical assistance.

\section{References}

Karzon, D.T. \& BARRon, A.L. (1962) An epidemic of aseptic meningitis syndrome due to ECHO virus type 6. Pediatrics, 29, 409, 418 and 432.

KibricK, S. (1964) Current status of Coxsackie and ECHO viruses in human disease. Progress in Medical Virology, 6 , 27.

Lepow, M.L., Carver, D.H., Wright, Jr, H.T., Woods W.A. \& Robrins, F.C. (1962) A clinical, epidemiologic and laboratory investigation of aseptic meningitis during the four-year period 1955-1958. New England Journal of Medicine, 266, 1181.

Peckham, C.S. (1964) ECHO virus infections in England and Wales, 1959-63. Monthly Bulletin of the Ministry of Health and The Public Health Laboratory Service, 23, 217.

Sommerville, R.G. (1958) Enteroviruses and diarrhoea in young persons. Lancet, ii, 1347.

WEBB, H.E. (1968) Factors in the host-virus relationship which may affect the course of an infection. British Medical Journal, 4, 684.

Winkelstein, W., Karzon, D.T., Barron, A.L. \& Hayner, N. (1957) Epidemiological observation on an outbreak of aseptic meningitis due to ECHO virus type 6. American Journal of Public Health, 47, 741.

Yuceoglu, A.M., Berkovich, A. \& Minkowitz, S. (1966) Acute glomerulonephritis associated with ECHO virus type 9 infection. Journal of Paediatrics, 69, 603.

SCIENCE (1955) Committee on the ECHO viruses: enteric cytopathogenic human orphan viruses. 122, 1187. 